\title{
Development and characterisation of synbiotic whey beverage
}

\author{
M Dharani Kumar ${ }^{1}$, M Anupama ${ }^{2}$, M Davuddin Baig ${ }^{3}$, AK Beena ${ }^{4}$ and SN Rajakumar ${ }^{5}$
}

Received: 10 February 2021 / Accepted: 20 April 2021 / Published online: 27 July 2021

(c) Indian Dairy Association (India) 2021

\begin{abstract}
Synbiotic foods has revolutionised the status of functional foods socially as well as commercially. The stringent environmental rules over disposal of whey and it's high nutritional value has driven industries to develop new whey based functional products. Among developed whey-based products fermented products has got significant position. In this study authors optimized a synbiotic whey beverage and also analysed for its proximate composition and storage stability. The developed synbiotic product had possessed following physico-chemical parameters: $\mathrm{pH} 3.67$, acidity 0.90 per cent Lactic acid (LA), moisture $82.92 \%$, total solids $17.08 \%$, lactose $4.72 \%$, protein $0.43 \%$ and fat $0.25 \%$. The beverage was found to have a probiotic count of $9.22 \log _{10} \mathrm{cfu} / \mathrm{ml}$. Coliforms, yeast and molds counts were found to be absent for a period of 9 days. Rheological properties of whey beverage revealed that the product had a shear thinning behaviour with higher loss modulus (G") values indicating viscous behaviour. Under refrigeration the drink started showing sign of spoilage from tenth day of storage. The required probiotic count was maintained in the product till $9^{\text {th }}$ day of refrigerated storage as per legal requirement of FAO/ WHO (2002). From study it can be inferred that newly developed synbiotic whey drink has got shelf life of 9 days under refrigeration.
\end{abstract}

Keywords: Beverage, flow behaviour, Synbiotic, whey

\footnotetext{
${ }^{1,2,3}$ Department of Dairy Technology, College of Dairy science and Technology, Mannuthy, KVASU, Kerala, India

${ }^{4}$ Department of Dairy Microbiology, College of Dairy science and Technology, Mannuthy, KVASU, Kerala, India

${ }^{5}$ Department of Dairy Technology, College of Dairy science and Technology, Mannuthy, KVASU, Kerala, India

M Dharani Kumar ( $\square)$

Department of Dairy Technology, College of Dairy science and Technology, Mannuthy, KVASU, Kerala, India

Email: kumar.dharani1@gmail.com; Mobile+919581221747
}

\section{Introduction}

Whey is a major by-product of cheese-making and casein manufacturing industry (Athira, et al. 2015). Whey is a green liquid obtained after coagulation of casein through action of chymosin (rennet) or mineral/organic acid. It has a yellow/green colour, or sometimes even a bluish tinge, but the colour depends on the quality and type of milk used (Mann et al. 2019). Nearly half of the total solids present in milk i.e. 6.4-7\% are transferred to whey. Whey from paneer was reported to have $6.4 \%$ total solids, $0.5 \%, 5.0 \%$ lactose and $0.5 \%$ mineral (Gupta and Singh, 2007). Apart from being a precious source of proteins, minerals and vitamins it is also a rich source of essential amino acids. The measure of amount of protein nitrogen that is retained by the body from a given amount of protein nitrogen that has been consumed is called 'Biological Value (BV)'. Whey proteins have high biological value (107) when compared to casein (77), egg (88) and soya proteins (59). The Protein Efficiency Ratio (PER) is used as a measure of growth expressed in terms of weight gain of an adult by consuming one gram of food protein. The protein efficiency ratio value of whey protein is three which is higher than wheat (1.00), rice (1.25), soya (2.12) and casein (2.50). The nutritive value of whey protein is next to that of egg proteins (Ganguly et al. 2019).

Despite of presence of valuable nutrients and functional bioactive peptides in whey, a large quantity is being unutilized owing its inferior sensory property. The drainage of whey into sewage also creates serious environmental problems owing to its high BOD content (30-60 g O $\mathrm{O}_{2} / 1$ ) (Alvarez, et al. 2020). So a wide range of whey product developments like whey-protein concentrates, whey protein isolates (Liu et al. 2000), whey beverages and whey cheese are active consideration for complete utilization of nutrients present in whey. The whey beverages majorly includes fruit flavoured, fruit juice blended, carbonated, fermented, alcoholic whey beverages and nutrient enriched whey drinks (Kumar et al. 2013). In functional food market there is increased demand for the production of probiotic fermented beverages owing to their health beneficial effects and nutritional properties (Sabokbar and Khodaiyan 2015). However, in fermented whey beverages, probiotic viability during processing, storage and distribution remained a major challenge. Flavor of beverage 
determines different desirable sensory characteristics. In order to increase consumer acceptability, the typical whey flavour drives to extraneous addition of flavor compounds. Citrus fruit and citrus fruit based flavors are being used to mask the unappealing taste of whey. In this context present study had been conducted to optimize synbiotic whey beverage and characterize the product in terms of its compositional, rheological and storage properties.

\section{Materials and Methods}

\section{Collection and maintenance of culture}

Lactobacillus casei (NCDC 298) was procured from National Collection of Dairy Cultures (NCDC), Karnal. Culture was activated in sterilized skim milk. Three consecutive transfers were done for maximum activation of culture. Routine maintenance of culture was carried out fortnightly in sterilized whey. In between the transfers, cultures were kept at-refrigerated temperature.

\section{Preparation of synbiotic whey beverage}

The buffalo milk whey was collected from University Dairy Plant, Kerala Veterinary and Animal Sciences University (KVASU), Mannuthy. It was filtered through muslin cloth and total solids content of whey was adjusted to 5.5 percent by adding pasteurised water. Inulin (Brenntag connecting chemistry company, India; $0.69 \% \mathrm{w} / \mathrm{v}$ of whey) and orange flavour (Sonarome, India) were added to the whey at $60^{\circ} \mathrm{C}$ followed by pasteurization at $72^{\circ} \mathrm{C} / 15 \mathrm{sec}$. Pasteurized whey was inoculated with $1.5 \% \mathrm{~L}$. casei at $40^{\circ} \mathrm{C}$. Then it was incubated at $37^{\circ} \mathrm{C}$ for 16 h. Appropriate quantity of sugar was weighed and dissolved in pasteurized water (3:1 ratio) and then added aseptically to fermented whey at $37^{\circ} \mathrm{C}$. The prepared product was packed in sterilized glass bottles and stored at refrigerated temperature.

For sugar optimisation, sugar was added at four different levels viz. 9\% (TS1), 11\% (TS2), 13\% (TS3) and 15\% (TS4) while flavour was added at a constant level of $0.03 \% \mathrm{w} / \mathrm{v}$. For flavour optimisation Flavour was added at four different levels viz. $0.01 \%$ (T1), $0.02 \%$ (T2), $0.03 \%$ (T3) and $0.04 \%$ (T4) while sugar was added at a constant level of $11 \% \mathrm{w} / \mathrm{v}$.

\section{Sensory evaluation}

Sensory evaluation of synbiotic whey beverage was carried out using 9- point Hedonic scale. The samples were drawn from the refrigerator immediately before serving to the panellists. Sensory evaluation panel consisted of five judges having adequate knowledge about the sensory evaluation methods and product characteristics were chosen from the faculty of College of Dairy Science and Technology, Thrissur. Sensory characteristics such as flavour, mouthfeel, appearance and overall acceptability were evaluated.

\section{Physico-chemical analysis}

$\mathrm{pH}$ of product was determined by using $\mathrm{pH}$ meter (Systronics, $\mathrm{pH}$ meter 361 ). The titratable acidity, protein, lactose and moisture of the sample was determined by the method recommended by AOAC (1990) for milk.

\section{Color values}

Color values $\left(L^{*}, a^{*}, b^{*}\right)$ of synbiotic whey beverage were measured using "Color-flex" colorimeter (MiniScan XE Plus, Hunter Associates Laboratory, Reston, Virginia, USA). Before the test, of the instrument was calibrated with standard black and white tiles as specified by the manufacturer. The output given by instrument was expressed in terms of CIELAB system.

\section{Rheological analysis}

The rheological measurement of whey beverage was performed by using dynamic rheometer (MCR 52, Anton paar, Ostifildern, Germany) fitted with cone and plate configuration (CP-75) of 75 $\mathrm{mm}$ diameter at $25^{\circ} \mathrm{C}$. The product was loaded on rheometer base plate and allowed to rest for 10 minutes to maintain uniform temperature and to prevent the influence of structure modification during sample handling and loading. The flow curve of the symbiotic whey beverage was determined at $25^{\circ} \mathrm{Cat}$ variable shear rates ranging from 0 to $100 \mathrm{~s}^{-1}$. The data was fitted to power law rheological model. For dynamic viscoelastic determination, rheological measurements were performed by frequency sweep test within the LVE range of the product. The rheological spectra was obtained recording dynamic complex viscosity $\left(\mathrm{n}^{*}\right)$, storage modulus (G') and loss modulus (G') as a function of frequency $(1$ to $100 \mathrm{~Hz}$ ). Each test was carried out in triplicate.

\section{Microbiological analysis}

Probiotic count of each sample was estimated by pour plate technique, as described by Harrigan et al. (1989). Coliform, yeast and mold count of each sample was estimated by as per procedure outlined in IS: SP IX (1981).

\section{Storage stability of synbiotic whey beverage}

The optimized product was packed in glass bottles and kept at refrigerated temperature $\left(5^{\circ} \mathrm{C}\right)$ for shelf-life study. The shelf-life of the synbiotic whey drink was assessed at three days intervals till spoilage. The changes in physico-chemical, microbiological and sensory parameters were assessed in the shelf -life study.

\section{Statistical analysis}

The results were analysed with SPSS v.16.0 for Windows software (SPSS South Asia (P) Limited, Bangalore, India). The data produced during optimization of sugar and flavour was analysed statistically using Krushkal-Wallis test followed by Mann- 
Whitney u-test. The variation between different periods of measurements in the case of data related to probiotic count, $\mathrm{pH}$, acidity, fat, lactose, moisture and total solids was analysed using repeated measures of ANOVA. In the case of storage study, sensory scores between measurements variability was analysed by using Friedman's test followed by Wicoxcan signed rank test.

\section{Results and Discussion}

\section{Optimization of sugar level of synbiotic whey beverage}

The data produced during sugar optimization was statistical analysed and results are presented in Table 1. Chi-square values were found to be significant $(\mathrm{p}<0.01)$ for all attributes indicating that there exist significant difference between treatments with respect to all attributes. Sugar percent has a significant effect on the mouthfeel, sweetness and total solids of synbiotic whey drink. Highest overall acceptability score (7.46) was obtained for the treatment TS2 which had a sugar content of $11 \%$ as compared to all other treatments. The relatively lower sensory scores was observed in of synbiotic whey beverage containing $15 \%$ sugar. This may be due to the higher sweetness that resulted majorly from added sugar and to a little extent form inulin. Niness (1999) reported that inulin also contributes to sweet taste in foods nearly one tenth of sucrose sweetness. The panellists rated higher scores for TS2 treatment for overall acceptability and other sensory parameters. Hence sugar content was optimized to $11 \%$ in the synbiotic whey beverage. The amount of sugar optimized in various whey based beverages was reported to be in between 7-12\% (Sthavarmath and Puranik 2018; Singh et al. 2014). Whey based low alcoholic ( $<1 \%$ alcohol) beverage called 'wheyvit' was developed by Bambha et al. (1972). It was reported to have a total sugar content of $10-11 \%$. Optimised sugar content of this study much lower than sugar content in fermented whey beverage reported by Saha et al. (2017). However the perception of sweet taste varies with individual, age, gender and taste receptor genotypes (Mennella et al. 2018).

\section{Optimization of flavour level of synbiotic whey beverage}

Flavour was added to enhance the taste-and improve sensory acceptability so as to mask the unpalatable salty taste of the final product. Data generated during flavor optimization was statistically analysed and results are presented in Table 2. Chisquare values was found to be Significant $(\mathrm{p}<0.01)$ for colour and appearance, mouthfeel, flavour and overall acceptability. Whereas sweetness values were found to be significant at 5\% level of significance. Hence there exists a significant $(\mathrm{p}<0.05)$ difference between the treatments in respect to these attributes. No significant $(\mathrm{p}>0.05)$ difference was observed in terms of overall acceptability between T2 and T3. However, a mean score for overall acceptability was highest for the treatment T3 $(8 \pm 0.05)$. Therefore, T3 was selected as optimised flavour percent.

\section{Proximate composition of formulated synbiotic whey beverage}

The final product was prepared by adding optimized level of sugar and flavor and its proximate composition was presented in Table 3 . The moisture and total solids content of the synbiotic whey beverage developed in this study was found to be 82.92 and 17.08 per cent respectively. The protein and fat content of the product was 0.43 and $0.25 \%$ respectively per cent. The respective $\mathrm{pH}$ and titratable acidity of the freshly developed synbiotic whey beverage in this study was 3.67 and 0.9 per cent

Table 1 Effect of different levels of sugar on sensory attributes of synbiotic whey beverage

\begin{tabular}{llllll}
\hline Parameter & TS1 & TS2 & TS3 & TS4 & Chi- square value \\
\hline Color \& appearance & $6.44 \pm 0.18^{\mathrm{b}}$ & $7.3 \pm 0.17^{\mathrm{a}}$ & $6.9 \pm 0.15^{\mathrm{b}}$ & $6.63 \pm 0.19^{\mathrm{b}}$ & $9.425^{* *}$ \\
Mouthfeel & $7.06 \pm 0.17^{\mathrm{b}}$ & $7.33 \pm 0.12^{\mathrm{a}}$ & $7 \pm 0.1^{\mathrm{b}}$ & $6.3 \pm 0.13^{\mathrm{b}}$ & $9.238^{* *}$ \\
Sweetness & $6.87 \pm 0.24^{\mathrm{b}}$ & $7.43 \pm 0.3^{\mathrm{a}}$ & $7.03 \pm 0.12^{\mathrm{b}}$ & $6.46 \pm 0.17^{\mathrm{b}}$ & $9.877^{* *}$ \\
Flavour & $7.13 \pm 0.29^{\mathrm{b}}$ & $7.53 \pm 0.06^{\mathrm{a}}$ & $7.27 \pm 0.37^{\mathrm{b}}$ & $6.67 \pm 0.06^{\mathrm{b}}$ & $8.897^{* *}$ \\
Overall acceptability & $6.63 \pm 0.18^{\mathrm{a}}$ & $7.46 \pm 0.06^{\mathrm{a}}$ & $7 \pm 0.1^{\mathrm{a}}$ & $6.47 \pm 0.11^{\mathrm{a}}$ & $5.90^{* *}$ \\
\hline
\end{tabular}

Figures are the Mean \pm Standard error of three replications, ${ }^{* *}$-significant at one percent level $(\mathrm{p}<0.01),{ }^{\mathrm{a}-\mathrm{b}}$ figures in row bearing different superscripts differ significantly

Table 2 Effect of different levels of flavour on sensory attributes of synbiotic whey beverage

\begin{tabular}{llllll}
\hline Parameter & T1 & T2 & T3 & T4 & Chi- square value \\
\hline Color \& appearance & $6.33 \pm 0.18^{\mathrm{ab}}$ & $7.5 \pm 0.15^{\mathrm{a}}$ & $8.12 \pm 0.13^{\mathrm{a}}$ & $6.3 \pm 0.52^{\mathrm{ac}}$ & $13.776^{* *}$ \\
Mouthfeel & $6.17 \pm 0.15^{\mathrm{ac}}$ & $7.47 \pm 0.1^{\mathrm{a}}$ & $7.97 \pm 0.08^{\mathrm{a}}$ & $6.3 \pm 0.37^{\mathrm{bc}}$ & $14.02^{* *}$ \\
Sweetness & $6.93 \pm 0.22^{\mathrm{ac}}$ & $7.43 \pm 0.24^{\mathrm{a}}$ & $7.97 \pm 0.15^{\mathrm{a}}$ & $6.6 \pm 022^{\mathrm{ab}}$ & $12.84^{*}$ \\
Flavor & $6.5 \pm 0.27^{\mathrm{ab}}$ & $7.43 \pm 0.14^{\mathrm{a}}$ & $8.1 \pm 0.12^{\mathrm{a}}$ & $6.4 \pm 0.34^{\mathrm{ac}}$ & $13.174^{* *}$ \\
Overall acceptability & $6.57 \pm 0.12^{\mathrm{ab}}$ & $7.34 \pm 0.15^{\mathrm{a}}$ & $8 \pm 0.05^{\mathrm{a}}$ & $5.97 \pm 0.35^{\mathrm{cd}}$ & $14.02^{* *}$ \\
\hline
\end{tabular}

Figures are the Mean \pm Standard error of three replications, ${ }^{* *}$-significant at one percent level $(\mathrm{p}<0.01)$, ${ }^{\mathrm{a}-\mathrm{b}}$ figures in row bearing different superscripts differ significantly 
Fig. 1 Sensory characteristics of formulated fresh synbiotic whey beverage

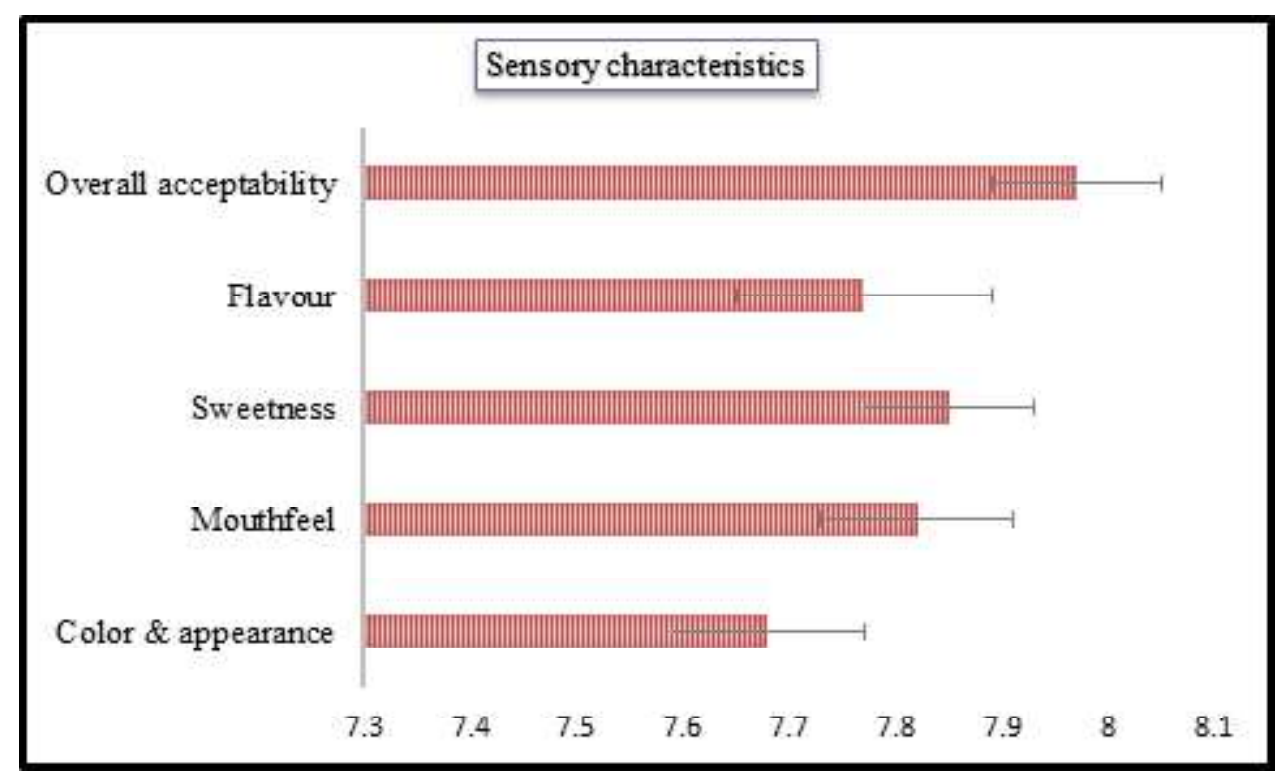

Table 3 physico chemical, color and microbiological analysis of formulated synbiotic whey drink

\begin{tabular}{ll}
\hline Attribute & Observed values \\
\hline Moisture (\%) & $82.92 \pm 0.33$ \\
Total solids (\%) & $17.08 \pm 0.33$ \\
Fat (\%) & $0.25 \pm 0.02$ \\
Protein (\%) & $0.43 \pm 0.02$ \\
Lactose (\%) & $4.72 \pm 0.03$ \\
pH & $3.67 \pm 0.33$ \\
Titratable acidity (\%LA) & $0.90 \pm 0.34$ \\
Color values & \\
L* $^{*}$ & $20.78 \pm 0.09$ \\
a* & $9.39 \pm 3.41$ \\
$b^{*}$ & $25.18 \pm 2.73$ \\
Probiotic count $\left(\log _{10} \mathrm{cfu} / \mathrm{ml}\right)$ & $9.22 \pm 0.012$ \\
Coliform count & Nil \\
Yeast and mould count & Nil \\
\hline
\end{tabular}

lactic acid (LA). The total lactose in the synbiotic whey beverage was 4.72 per cent which is slightly lower than the values reported for whey 5.2\% (Gupta and Singh 2007). This decrease in lactose content can be attributed to fermentation of lactose to lactic by Lactobacillus casei NCDC 298. Conversion of lactose to lactic acid during fermentation of whey also reported by Vesa et al. (2000). The chemical composition of beverage is almost similar to that reported for various whey beverages (Sakhale et al. 2012; Singh et al. 2012). However the addition of inulin to the fermented whey beverage resulted slightly in total solids content than that of unfermented whey (data not shown). Similar trend of increase with addition of XOS also observed in strawberry-flavoured whey beverage (Souza et al. 2019). Color is an important characteristic of food from consumer's acceptability point of view. The $L^{*}$ value is a measurement of lightness and varies from 0 (black) to 100 (white); the $\mathrm{a}^{*}$ value varies from -100 (green) to +100 (red); and the $b^{*}$ value varies from -100 (blue) to +100 (yellow). Lightness $\left(\mathrm{L}^{*}\right)$, Redness $\left(\mathrm{a}^{*}\right)$ and Yellowness $\left(\mathrm{b}^{*}\right)$ values of prepared beverage was $\sim 20.78,9.39$ and 25.18 respectively. For neutral colors (white, gray or black) L*, a* and b* values approach zero, while with rise of these values, the color becomes more saturated or chromatic (Baccouche et al. 2013).

\section{Microbial quality of synbiotic whey beverage}

The viable Lactobacillus count of the synbiotic whey beverage was found to be $9.22 \log _{10} \mathrm{cfu} / \mathrm{ml}$ (Table 3). "According to the guidelines stipulated by FAO/ WHO (2002) the probiotic strains should retain a viable count of at least $10^{7} \mathrm{cfu} / \mathrm{ml}$ to exert the beneficial effect on the host". The results in this study indicate that synbiotic whey beverage fulfills specifications of FAO/WHO (2002). The absence of coliform count and yeast and mold suggest that adaption of hygienic practices during production ensured quality of the product. Moreover the high intrinsic acidity of synbiotic whey beverage suppressed the undesirable flora. The absence of coliforms and yeast and mold has been reported in earlier studies on probiotic whey based beverages also (Vandana et al. 2014).

\section{Sensory characteristics of synbiotic whey beverage}

The sensory scores of the synbiotic whey beverage (Fig. 1) in terms of colour and appearance, mouthfeel, sweetness, flavour and overall acceptability was found to be $7.68,7.82,7.85,7.77$ and 7.97 respectively on a 9 point hedonic scale. The developed synbiotic whey beverage has shown a overall acceptability score of 7.97 which is good indicative of the acceptable organoleptic quality for whey-based product. 

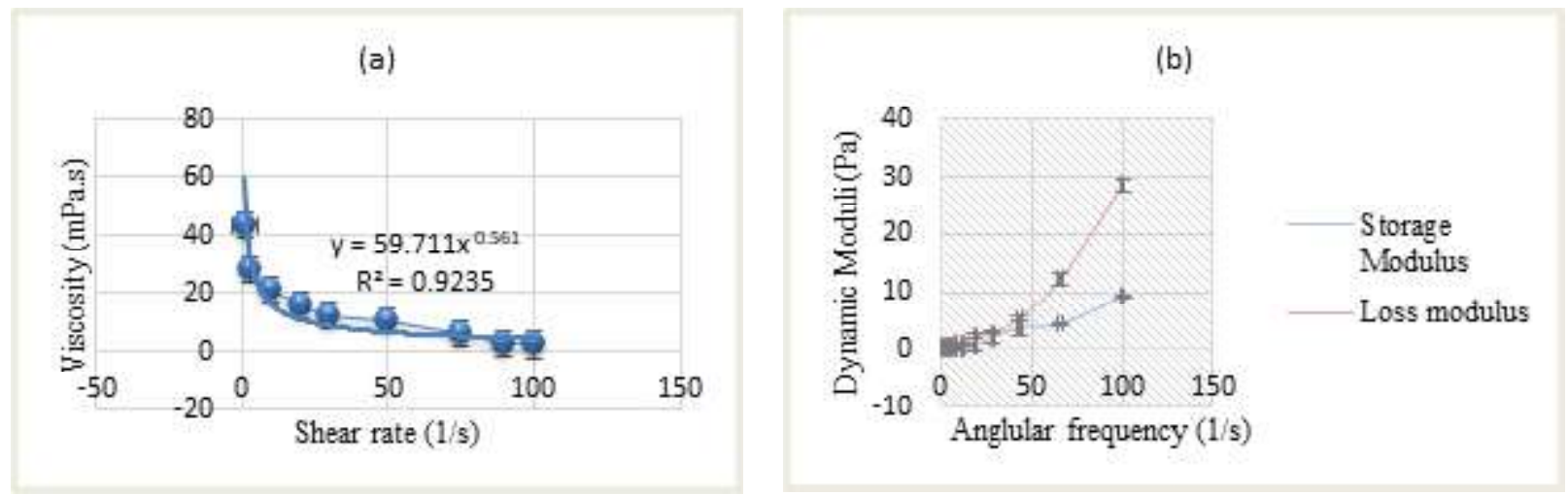

Fig. 2 (a) Flow curve (b) Dynamic Moduli of synbiotic whey beverage
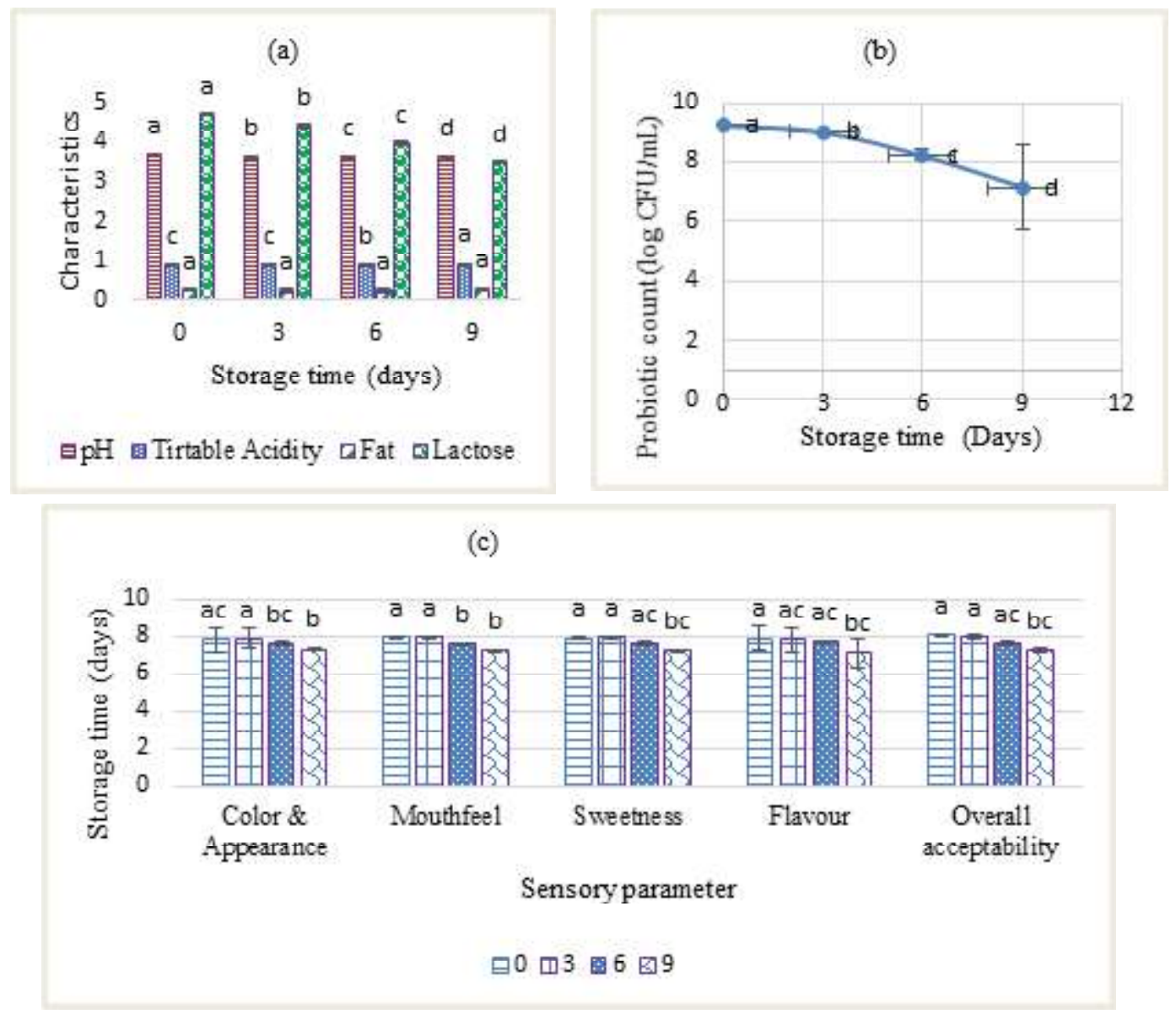

Fig. 3 (a) Changes in physico chemical (b) probiotic count (c) sensory characteristics of synbiotic whey beverage during storage period

\section{Rheological properties of synbiotic whey beverage}

Several rheological models have been studied to fit the viscosity data on lactic fermented whey beverages (Penna et al. 2003). The power law model has been used in modelling the flow behaviour of probiotic dairy beverages (Castro et al. 2013). The power law has expressed below

$$
\sigma=K(\gamma)^{n}
$$

here $\sigma$ is the shear stress $(\mathrm{Pa}), \mathrm{k}$ is the consistency index $\left(\mathrm{Pa} \cdot \mathrm{s}^{\mathrm{n}}\right), \gamma$ is the shear-rate $\left(\mathrm{s}^{\prime \prime}\right)$, and $\mathrm{n}$ is the flow index. The power law model was found suitable in this study to-express the shear stress data of the whey beverage at increasing shear rate. The consistency index $(\mathrm{K})$, flow behaviour index $(\mathrm{n})$ and correlation 
coefficient $\left(\mathrm{R}^{2}\right)$ values for the model fit was 59.71, 0.561 and 0.826 respectively.

The viscosity of synbiotic whey beverage as a function of shear rate was graphically shown in Fig. 3 (a). The apparent viscosity of the synbiotic whey beverage was $10.6 \mathrm{mPa}$ s at $25^{\circ} \mathrm{C}$ and $50 \mathrm{~s}$ ${ }^{1}$ shear rate. Viscosity values of different fermented whey beverages made with different commercial probiotics were between 8 and $23.3 \mathrm{mPa}$ s (Bulatovic et al. 2014; Oliveira et al. 2002). Generally, viscosity of the beverages decreased with increasing shear rate indicating a non-Newtonian behaviour (Masson et al. 2011). Synbiotic whey beverage has shown shear thinning behavior $(\mathrm{n}<1)$. Similar type of flow behaviour for prebiotic whey beverage also reported by Guimaraes et al. (2018).

The G' value is a measure of the deformation energy stored in the sample during the shear process, representing the elastic behavior of a sample. In contrast, the G" value is a measure of the deformation energy used up in the sample during shear and lost to the sample afterward, representing the viscous behavior of a sample. As shown in Fig. 3 (b), loss modulus (G") values were higher than the storage modulus ( $\left.G^{\prime}\right)$ indicating viscous behaviour as for liquids. The observed results were in line with the results reported for fermented probiotic dairy beverage by Castro et al. (2013).

\section{Storage stability of synbiotic whey beverage}

The shelf-life assessment of the freshly prepared synbiotic whey beverage under refrigerated storage was done based on the changes in physico-chemical, microbiological, and sensory parameters at three days interval $\{$ Fig 3 (a), (b) \& (c) $\}$. From the results obtained during the storage period of 10 days, a decline in the $\mathrm{pH}$ was observed with values ranging from 3.66 to 3.62 with significant decrease $(\mathrm{p}<0.05)$. The titratable acidity slightly increased from 0.902 to 0.922 per cent Lactic acid (LA) was observed during the storage period from $0^{\text {th }}$ day to $9^{\text {th }}$ day. The titratable acidity of the synbiotic whey beverage increased significantly from three days to the end of the shelf-life. The similar results for probiotic drinks in terms of $\mathrm{pH}$ and titratable acidity values has been reported by various researchers (Vikram et al. 2011; Daneshi et al. 2012). The synbiotic whey beverage has shown a non-significant $(\mathrm{p}>0.05)$ changes in fat, moisture and total solids whereas lactose content changed significantly $(\mathrm{p}<0.001)$ from $4.708 \%$ on $0^{\text {th }}$ day to $3.48 \%$ on $10^{\text {th }}$ day of storage. The decrease in lactose content was due to the conversion of lactose present in whey to lactic acid because of fermentation. Hikmetoglu et al. (2020) also observed similar trends in lactose content of kefir i.e. from $2.8 \mathrm{~g} / 100 \mathrm{~g}$ on first day to 0.3 $\mathrm{g} / 100 \mathrm{~g}$ on $7^{\text {th }}$ day of storage.

The mean scores for changes in sensory attributes of synbiotic whey beverage during storage are presented in Fig 3 (c). The mean scores of all studied attributes during 10 days of storage are highest on $0^{\text {th }}$ day but lowest on $9^{\text {th }}$ day with significant difference $(\mathrm{p}<0.01)$. Sensory scores for overall acceptability of the synbiotic whey beverage decreased significantly $(p<0.01)$ from 8.04 to 7.22 . However there was no significant difference between $0^{\text {th }}, 3^{\text {rd }}$ and $6^{\text {th }}$ day.

The functional food claiming the status of synbiotic or probiotic product, minimum probiotic count that is necessary to exert their beneficial effect is $10^{6}$ to $10^{7} \mathrm{cfu} / \mathrm{ml}$ (FSSAI, 2006). In the present study, viable Lactobacillus count of the synbiotic whey beverage decreased significantly $(\mathrm{p}<0.05)$ during the 10 days of storage. One log reduction in the viable count of synbiotic whey beverage was observed during 10 days of storage (Fig. 3 (b)). The possible reason for decrease in the L. casei NCDC 298 count was due to the physiological state of this strain. Similar trend in decrease of probiotic count also reported by Ismail et al. (2011) in whey based mango beverage. However the synbiotic whey beverage retained the recommended levels of live cells required to exert their beneficial effect up to 9 days of storage. The synbiotic whey beverage had shelf life of nine days under refrigerated storage. Vandana et al. (2014) also observed the 10 days keeping quality for fermented probiotic whey beverage. Heller (2001) reported that bacteria undergo more stress under storage conditions than cells in stationary phase during transition between the exceptional phase and the stationary phase. The $\mathrm{pH}$ values $\mathrm{d}$ " 4.5 of probiotic foods can also effect the survivability of probiotic count (Gorski 1995). Our observation of storage stability of 9 days was in line with Saha et al. (2017), who also observed similar storage stability for channa whey fermented whey beverages.

\section{Conclusions}

Synbiotics are the synergistic combination of probiotics and prebiotics which helps in accomplishment of health benefits in host. Whey is a nutrient rich by-product of dairy industry which is not being utilized properly and disposed. Synbiotic whey beverage developed in this study is a good option for utilization of whey and valorisation of whey into a functional dairy product.

\section{Acknowledgments}

Authors would like to thank Kerala Veterinary and Animal Sciences University (KVASU) for financial support in the form of research grant and all the faculty of College of Dairy Science and Technology, Mannuthy for their endless support.

\section{References}

Alvarez-Guzman CL, Cisneros-de la Cueva S, Balderas-Hernández VE, Smoliński A and De León-Rodríguez A. (2020) Biohydrogen production from cheese whey powder by Enterobacter asburiae: Effect of operating conditions on hydrogen yield and chemometric study of the fermentative metabolites. Energy Reports 6: 1170-1180

AOAC (1990) Official methods of analysis. (15 ${ }^{\text {th }}$ Ed.). Association Official Agriculture Chemists, Washington DC, USA 
Athira S, Mann B, Saini P, Sharma R, Kumar R, Singh AK (2015) Production and characterisation of whey protein hydrolysate having antioxidant activity from cheese whey. J Sci Food Agric 95: 2908-2915

Baccouche A, Ennouri M, Felfoul I, Attia H. (2013) A physical stability study of whey-based prickly pear beverages. Food Hydrocolloids 33: 234-244

Bambha PP, Setty PAS, Nambudripad VKN (1972) "Whevit"—a nourishing soft drink. Indian Dairyman

Bulatovic ML, Krunic TZ, Vukasinovic-Sekulic MS, Zaric DB, Rakin MB (2014) Quality attributes of a fermented whey-based beverage enriched with milk and a probiotic strain. RSC Advances 4: 5550355510

Castro WF, Cruz AG, Bisinotto MS, Guerreiro LMR, Faria JAF, Bolini HMA, Deliza R (2013) Development of probiotic dairy beverages: Rheological properties and application of mathematical models in sensory evaluation. J Dairy Sci 96:16-25

Daneshi M, Ehsani MR, Razavi SH, Labbafi M (2012) Effect of refrigerated storage on the probiotic survival and sensory properties of milk/ carrot juice mix drink. Electronic J Biotech 16: 0717- 3458

FAO/WHO [Food and Agriculture Organization/ World Health Organization] (2002) Guidelines for evaluation of probiotics in food: Report of a Joint FAO/WHO working group on drafting guidelines for the evaluation of probiotics in food. London, Ontario, Canada

FSSAI (2006) Food Safety and Standards Act (2006), Rules and Regulation (2011). ( $7^{\text {th }}$ Ed.). New Delhi, India

Ganguly S, Sabikhi L, Singh AK (2019) Effect of whey-pearl millet-barley based probiotic beverage on Shigella-induced pathogenicity in murine model. J Funct Foods 54: 498-505

Gorski D (1995) International dairy foods: A culturally different world. Dairy Foods 96: 30-32

Guimaraes JT, Silva EK, Costa ALR, Cunha RL, Freitas MQ, Meireles MAA, Cruz AG (2018) Manufacturing a prebiotic whey beverage exploring the influence of degree of inulin polymerization. Food Hydrocolloids 77: 787-795

Gupta and Singh S (2007) Utilization of whey. Indian Dairy Association series No. 004/TE, IDA press, New Delhi.pp 4

Harrigan P, Zieman JC and Macko SA (1989) The base of nutritional support for the gray snapper (Lutjanus griseus): an evaluation based on a combined stomach content and stable isotope analysis. Bull Marine Sci 44: 65-77

Heller KJ (2001) Probiotic bacteria in fermented foods: product characteristics and starter organisms. The Am J Clinical Nutr 73: 374s-379s

Hikmetoglu M, Sogut E, Sogut O, Gokirmakli C and Guzel-Seydim ZB (2020) Changes in carbohydrate profile in kefir fermentation. Bioact Carbohydr Dietary Fibre 23:100220

Ismail AE, Abdelgader MO, Ali AA (2011) Microbial and chemical evaluation of whey-based mango beverage. Adv J Food Sci Technol 3: $250-253$

Kumar S, Saxena D, Sabhiki L (2013) Developments in whey based beverages-A Review. Indian J Dairy Sci 66: 281-287

Liu G, Xiong YL, Butterfield DA(2000) Chemical, physical, and gel forming properties of oxidized myofibrils and whey and soy protein isolates. J Food Sci 65: 811-818

Mann B, Athira S, Sharma, R, Kumar R, Sarkar P (2019) Bioactive peptides from whey proteins. In Whey Proteins (pp. 519-547). Academic Press

Masson LM, Rosenthal A, Calado VM, Deliza R, Tashima L (2011) Effect of ultra-high pressure homogenization on viscosity and shear stress of fermented dairy beverage. LWT-Food Sci Technol 44: 495-501

Mennella, J A, Nolden AA, Bobowski N (2018) Measuring sweet and bitter taste in children: Individual variation due to age and taste genetics.
In Pediatric Food Preferences and Eating Behaviors (pp. 1-34). Academic Press

Niness KR (1999) Inulin and oligofructose: what are they? The J Nutr 129: $1402 \mathrm{~S}-1406 \mathrm{~s}$

Oliveira MND, Sodini I, Remeuf R, Tissier JP, Corrieu G (2002) Manufacture of fermented lactic beverages containing probiotic cultures. J Food Sci 67: 2336-2341

Penna ALB, Oliveira MN, Tamime AY (2003) Influence of carrageenan and total solids content on the rheological properties of lactic beverage made with yogurt and whey. J Texture Stud 34: 95-113

Sabokbar N, Khodaiyan F (2015) Characterization of pomegranate juice and whey based novel beverage fermented by kefir grains. J Food Sci Technol 52: 3711-3718

Saha P, Ray PR, Ghatak PK, Bag SK, Hazra T (2017) Physico-chemical quality and storage stability of fermented Chhana whey beverages. Indian J Dairy Sci 70: 398-403

Sakhale BK, Pawar VN, Ranveer RC (2012) Studies on the development and storage of whey based RTS beverage from mango cv. Kesar. J Food Processing Technol 3: 1-4

Singh AK, Singh K (2012) Utilization of whey for the production of instant energy beverage by using response surface methodology. Adv J Food Sci Technol 4: 103-111

Singh S, Khemariya P, Rai A (2014) Process optimization for the manufacture of lemon based beverage from hydrolyzed whey. J Food Sci Technol 51: 691-699

Souza, FP, Balthazar, CF, Guimarães, JT, Pimentel TC, Esmerino EA, Freitas MQ, Cruz AG (2019) The addition of xyloligoosaccharide in strawberry-flavored whey beverage. LWT-Food Sci Technol 109: 118-122

Sthavarmath S, Puranik DB (2018) Development of pomegranate blended whey beverage. Int J Sci Env Technol 7: 1040-1046

Vandana, Shilpa V, Hati S (2014) Physico-chemical and sensory quality of probiotic fermented Whey drink and its storage study. Indian J Dairy Sci 67: 133-138

Vesa TH, Marteau P, Korpela R (2000) Lactose intolerance. J Am College Nutr 19: 165S-175S

Vikram Simha HV, Sharanakumar H, Udaykumar nidoni, Ramachandra CT, Tamil vendan K, Prakash KV (2012) Comparative studies on spray-drying and freeze-drying of pomegranate (Punica granatum l. ) juice fermented with L. acidophilus. Int J Food Nutr Sci 1: 118127 